American Journal of Applied Sciences 8 (12): 1328-1336, 2011

ISSN 1546-9239

(C) 2011 Science Publications

\title{
Fluctuations of Phytoplankton Community in the Coastal Waters of Caspian Sea in 2006
}

\author{
${ }^{1,2}$ Siamak Bagheri, ${ }^{1}$ Mashhor Mansor, ${ }^{2}$ Marzieh Makaremi, ${ }^{2}$ Jalil Sabkara, \\ ${ }^{1}$ W.O. Wan Maznah, ${ }^{2}$ Alireza Mirzajani, ${ }^{2}$ Seyed Hojat Khodaparast, \\ ${ }^{2}$ Hossein Negarestan, ${ }^{2}$ Azemat Ghandi and ${ }^{1}$ Akbar Khalilpour \\ ${ }^{1}$ Plankton Laboratory, School of Biological Sciences, Universiti Sains Malaysia, \\ 11800 Penang, Malaysia \\ ${ }^{2}$ Inland Waters Aquaculture Institute, Iranian Fisheries Research \\ Organistion (IFRO), 66 Anzali, Iran
}

\begin{abstract}
Problem statement: The Caspian Sea ecosystem has been suffered with many problems since 1980s. Aanthropogenic pollution from heavy metals, hydrocarbons, pesticides, changes in the quantity of nutrient inputs by rivers, are significant threats to biodiversity and biological resources such as plankton structure in the Caspian Sea. According to the significant of phytoplankton community in marine system. The state of the fluctuations of phytoplankton communities of the southwestern Caspian Sea was investigated and compared with the findings of before 2006. Approach: Phytoplankton abundance and species composition of the Caspian Sea were evaluated by using samples collected at 12 stations along three transects. Samplings were conducted seasonal in 2006 at 5, 10, 20 and $50 \mathrm{~m}$ depth were fixed for each transect in the southwestern Caspian Sea. Results: A total of 39 species phytoplankton species were distinguished during 2006, the annual phytoplankton abundance were calculated as $57,300 \pm 15,550$ cells..$^{-1}$, which ranged from $89,250 \pm 35$, 062 cells. $1^{-1}$ in September to 16, 200 $\pm 6,664$ cells. $1^{-1}$ in February. The diatoms formed more than half of the total abundance $(61 \%)$ while cyanophytes were the second important group in view of contribution to total phytoplankton $(26 \%)$ in 2006 . The study showed that diatoms Thalassionema nitzschioides, Cyclotella meneghiniana and cyanophyte Osillatoria sp. numerically dominated in this area. Conclusion: The study revealed that diatoms were higher than other groups of phytoplankton in 2006. The hydrology variation, increased fresh water inflow via rivers and a rise in nutrients concentrations have played important roles in blooming of phytoplankton species, e.g., the diatoms in this study, which is also known from other marines. Similar studies on determination of the effects of environmental degradation on phytoplankton and hydrological processes should be taken into account in near future.
\end{abstract}

Key words: Abundance, cyanophytes, diatoms, phytoplankton, nutrient, caspian sea

\section{INRTODUCTION}

The Caspian Sea is the largest inland water body on earth; it is located at the far end of southeastern Europe, bordering Asia (Kosarev and Yablonskaya, 1994). Approximately, 130 rivers with various sizes drain into the Caspian Sea with an average annual input of about $300 \mathrm{~km}^{3}$. The most important river is Volga and provides about $80.0 \%$ of the total fresh water input (Dumont, 1998). The southwestren of the Caspian Sea receives 80 rivers; (the Sefidrood is the largest river with a $67,000 \mathrm{Km}^{2}$ catchment area and discharge of
4,037 million $\mathrm{m}^{3}$; Lahijani et al., 2008). The Anzali wetland is the other freshwater source, which with a catchment area of $3,740 \mathrm{~km}^{2}$, contributes about 2 million $\mathrm{m}^{3}$ of fresh water per year, this wetland has a passage to the Sea with the width of $426 \mathrm{~m}$ and 11 tributary rivers flow into the Anzali wetland (Sharifi, 2006). The salinity of the Caspian Sea ranges from 0.10-13.50 ppt from north to south. There is also a slight increase in salinity with depth (Kosarev and Yablonskaya, 1994). In the northern Caspian Sea, inorganic phosphate levels are on average 0.12-0.80 $\mu \mathrm{M}$. Nitrogen is largely present in organic form (10.0-

Corresponding Author: Siamak Bagheri, Plankton Laboratory, School of Biological Sciences, University Sains Malaysia, 1800 Penang, Malaysia Tel: + 60174220425 Fax: + 6046565125 
$\left.250.0 \mu \mathrm{g} .1^{-1}\right)$. Nitrate reaches up to $0.50 \mu \mathrm{M}$ in spring and summer and $10.0 \mu \mathrm{M}$ in winter. Silica shows a strong seasonal cycle and decreases from $60.0 \mu \mathrm{M}$ in winter to $<20.0 \mu \mathrm{M}$ in summer, when diatoms bloom (Dumont, 1998).

In an early study of phytoplankton in the Caspian, the total number of phytoplankton species found from 1962-1974 was 449 (Kosarev and Yablonskaya, 1994). These species consisted of 163 diatoms, 139 chlorophytes, 102 cyanophytes, 39 dinoflagellates, 5 euglenophytes and 1 chrysophyte. In addition, the species number was found to decrease from the north (414 species) to the middle (225 species) and the southern area (71 species) mainly due to the disappearance of fresh water forms towards the south (Dumont, 1998). Recently, Kideys et al. (2005; 2008) reported there was a significant increase in phytoplankton abundance and noxious visibility in the Caspian Sea. Moreover, Nasrollahzadeh et al. (2008a) and Bagheri et al. (2010) observed an increase in phytoplankton abundance in 2001-2002 and 2005 as compared to previous years. According to Khodaparast (2006) and Makaremi et al. (2007) cyanophytes Nodularia spumigena and dinoflagellates Heterocapsa sp. produced two anomalous algal blooms for the first time in the southwestern Caspian in September 2005 and October 2006. The increased nutrient load into the southwestern Caspian Sea caused an increase in primary productivity which was reflected by high chlorophyll $a$ levels (2.71-35.25 $\left.\mu \mathrm{g} . \mathrm{dm}^{-3}\right)$ in 2006 and the levels were $0.56-1.34 \mu \mathrm{g} . \mathrm{dm}^{-3}$ in 1994 (Khodaparast, 2006; CEP, 2006; Jamshidi et al., 2009). In the Caspian Sea, the fauna that have developed there are largely endemic and are therefore particularly susceptible to external influences (Dumont, 1998). There are also major anthropogenic impacts on the system originated from domestic pollutants (e.g., phosphorous-containing detergents), industrial pollutants (e.g., heavy metals and other industrial byproducts) and agricultural pollutants (e.g., nitrogen-containing fertilizers and pesticides). Furthermore, development of oil and gas fields creates stress on the ecosystem and its biological producers especially fish species (Salmanov, 1999; Aladin and Plotnikov, 2003). Stone (2002) described most of the acute problems in the Caspian Sea: reduction of the river run-off; the unstable water level; the various sources of pollution. Therefore, varied hydrological regimes and nutrient levels input by the Anzali wetland and the Sefidrood river can impact the phytoplankton structure in the coasts of southwestern Caspian Sea.

A few phytoplankton studies have been conducted on the south Caspian Sea in recent years (Nasrollahzadeh et al., 2008a, 2008b, 2008c; Roohi et al., 2010; Ganjian et al., 2010). They documented the annual and seasonal fluctuation of phytoplankton communities and nutrient concentrations in the southern Caspian from 1996-2005. The authors concluded that the comb jellyfish, ctenophores have played an important role in increasing in nutrients levels and phytoplankton populations in the Caspian after 2000, at present there is only a survey on the phytoplankton community in the southwestern Caspian Sea during 2001-2002 by Bagheri et al. (2010) and a few reports and local publications for this region. In order to investigate the situation that has developed since 2005, a new survey was undertaken in 2006. In this survey, the state of the composition of phytoplankton communities of the southwestern Caspian Sea was investigated and compared with the findings of before 2006.

\section{MATERIALS AND METHODS}

Phytoplankton abundance and species composition of the Caspian Sea were evaluated by using samples collected at 12 stations along three transects (Lisar, Anzali and Sefidrood) in the western Iranian coasts of the Caspian Sea. Samplings were conducted in 2006 (February, September, October, December), four stations located at $5 \mathrm{~m}$ (L1, A1, and S1), $10 \mathrm{~m}$ (L2, A2, and S2), $20 \mathrm{~m}$ (L3, A3 and S3) and $50 \mathrm{~m}$ (L4, A4, and S4) were fixed for each transect in the southwestern Caspian Sea (Fig. 1). Water samples were collected by using of Nansen water sampler 1.71 liter (Hydro-Bios, Germany, TPN; Transparent Plastic Nansen water sampler, No: 436201), water temperature level of the seawater at 5, 10, 20 and $50 \mathrm{~m}$ was measured in situ by using a reverse thermometer (Hydro-Bios, TPN) and salinity was estimated salinometer (Beckman; RS-7B, U.S. Patent, No: 2542057). Water transparency was determined with a Secchi disk depth. Water samples were deep frozen for analyses of inorganic nutrients. Dissolved Inorganic Phosphorus $\left(\mathrm{DIP}=\mathrm{P}-\mathrm{PO}_{4}\right)$, Dissolved Inorganic Nitrogen $\left(\mathrm{DIN}=\mathrm{N}-\mathrm{NO}_{2}, \mathrm{~N}-\mathrm{NO}_{3}, \mathrm{~N}-\mathrm{NH}_{4}\right)$ and dissolved Silicate $\left(\mathrm{DSi}=\mathrm{Si}-\mathrm{Sio}_{2}\right)$ were determined with a spectrophotometer system using standard methods (Clesceri et al., 2005).

Phytoplankton samples were collected from different depths with a Nansen water sampler. The samples were kept in $500 \mathrm{~mL}$ bottles and preserved using buffered formaldehyde $4 \%$. The samples were let to settle for at least 10 days following which the water was siphoned off from the top layer to a volume of approximately $250 \mathrm{~mL}$. 
Am. J. Applied Sci., 8 (12): 1328-1336, 2011

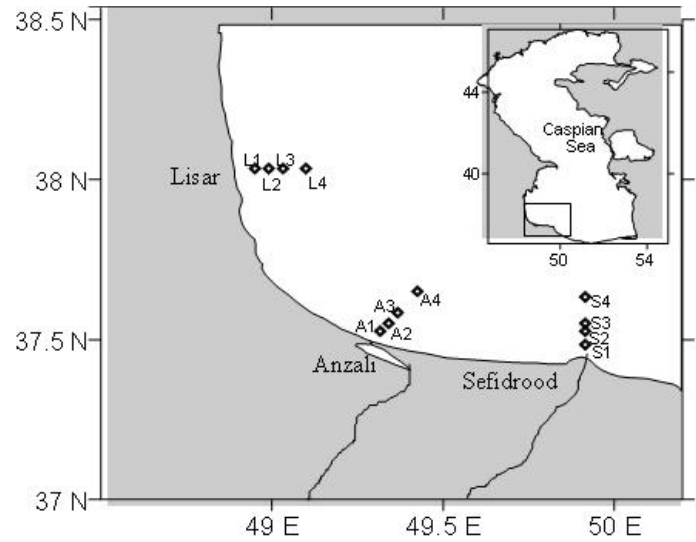

Fig. 1: Sampling transects and stations in the southwestern Caspian Sea in 2006

The samples were then centrifuged (ALC-PK131R; Germany, No: 30206372) for 5 min with $3000 \mathrm{rpm}$ and further siphoning off to a volume of $30 \mathrm{ml}$, phytoplankton present in a subsample of $0.1 \mathrm{ml}$ was counted using a Sedgewick-Rafter cell under a binocular microscope (cover slip $24 \times 24 \mathrm{~mm}$ and with magnifications of $10 \times, 20 \times$ and $40 \times$ ) (Prescott, 1962; Newell and Newell, 1977; Sournia, 1978; Clesceri et al., 2005). Phytoplankton taxonomic classification was performed based on Tiffany and Britton (1971). Statistical comparisons between months were made using statistical software SPSS version 13 for Windows. Analysis of variance comparisons (One-way ANOVA) for water parameters and nonparametric test (Kruskal-Wallis) for phytoplankton number were used to identify the importance of variables between different months. Spearman rank correlation coefficients (r) were used to evaluate the relationships between phytoplankton abundance and environment parameters.

\section{RESULTS}

No difference was noted in the spatial distribution of phytoplankton (non-parametric test; Kruskal-Wallis) and water parameters (one-way analyses of variance; ANOVA) between the three transects of Lisar, Anzali, and Sefidrood. Therefore, the data of the three transects were combined per months.

Hydrophysical characteristics: Temporal variations of surface temperature and salinity in the southwestern Caspian Sea in the period of February and December 2006 are demonstrated in Table. 1. The surface temperature ranged between 8.83 and $25.74^{\circ} \mathrm{C}$ due to monthly variations in weather temperature throughout year. Monthly temperature variations were significant (ANOVA, p<0.01).
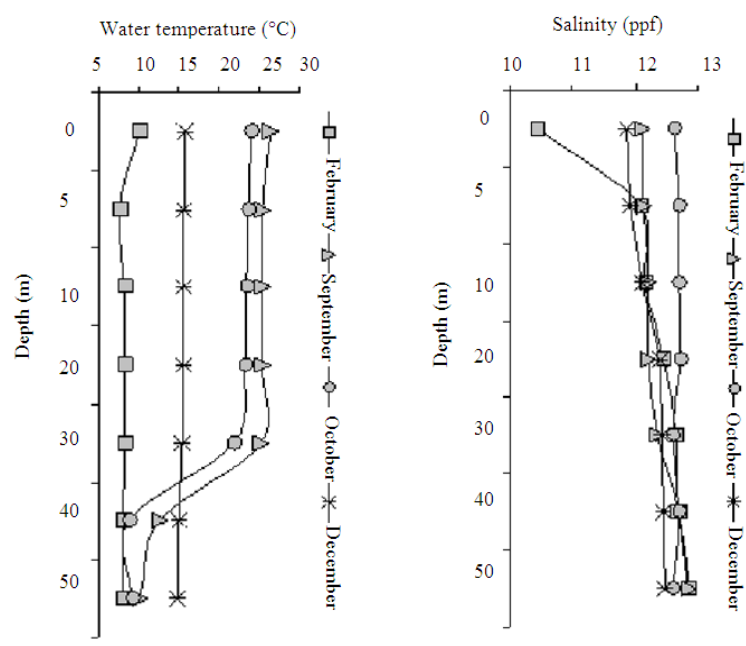

Fig. 2: Vertical profiles of water temperature and salinity at the station A4 of the Anzali transect in the southwestern Caspian Sea in 2006

The drastic thermocline was observed in September and October which formed in nearly $30 \mathrm{~m}$ depth. The average of water temperature varied between 25.7 , $9.7^{\circ} \mathrm{C}$, respectively in above and below of thermocline layers. In February and December, the temperature of the water column was nearly uniform, varying between $10-15.8^{\circ} \mathrm{C}$ at the surface and $8-14.9^{\circ} \mathrm{C}$ at the bottom, respectively (Fig. 2).

The variation of surface salinity was recorded as 9.32 and $12.25 \mathrm{ppt}$ in the southwestern Caspian Sea (Table 1). Based on the ANOVA findings, the salinity differences was not meaningful monthly $(\mathrm{p}>0.05)$ although a decreasing trend in the average salinity values was observed during February (Table 1). The gradient of salinity from surface to bottom is presented in Fig. 2 in which the salinity increase from 10.43 to $12.85 \mathrm{ppt}$, between surface and deep water (50 $\mathrm{m}$ depth) in the southwestern Caspian Sea. Temporal variations of Secchi disk depths in the period of February and December is presented in Table. 1. The Secchi disk depth, an indicator of water turbidity, the average Secchi disk depth was measured $5.0 \mathrm{~m}$ and changed between 3.8 and $6.4 \mathrm{~m}$, respectively in September and February during the study period. Statistical variance analysis (ANOVA) showed that Secchi disk depths were not significantly different between the months ( $p>0.05)$. Furthermore, the occurrence of Secchi disk depths was negatively correlated with phytoplankton abundance in this study $(\mathrm{r}=-0.870, \mathrm{p}<0.05)$. 
Am. J. Applied Sci., 8 (12): 1328-1336, 2011

Table 1: Hydro-physicochemical parameters $( \pm \mathrm{SD})$ at three transects and all stations in the southwestern Caspian Sea (Rivers discharge data by: GWRO, 2010)

\begin{tabular}{|c|c|c|c|c|c|c|c|c|c|}
\hline & Nutrient $(\mu \mathrm{M}$ & & & & & ppt & ${ }^{\circ} \mathrm{C}$ & $\mathrm{m}$ & million $\mathrm{m}^{3}$ \\
\hline Parameters & DIN & DIP & DSi & DSi:DIN & DSi:DIP & Salinity & Temperature & Secchi & Discharge \\
\hline February & $2.57 \pm 0.69$ & $0.63 \pm 0.40$ & $9.33 \pm 2.43$ & 3.6 & 15.04 & $9.32 \pm 2.67$ & $8.83 \pm 1.12$ & $6.4 \pm 2.3$ & 58 \\
\hline September & $2.15 \pm 0.82$ & $1.31 \pm 0.25$ & $8.24 \pm 4.43$ & 3.83 & 6.3 & $11.32 \pm 0.95$ & $25.74 \pm 0.33$ & $4.2 \pm 1.2$ & 33 \\
\hline October & $1.71 \pm 0.73$ & $1.02 \pm 0.37$ & $6.50 \pm 3.97$ & 3.8 & 6.37 & $12.25 \pm 0.36$ & $23.35 \pm 0.55$ & $4.5 \pm 1.7$ & 22.8 \\
\hline December & $1.45 \pm 0.05$ & $0.90 \pm 0.22$ & $7.31 \pm 6.23$ & 5.04 & 8.12 & $12.10 \pm 0.16$ & $15.80 \pm 0.60$ & $5.3 \pm 2.4$ & 49 \\
\hline Average & $1 . .97 \pm 0.49$ & $0.96 \pm 0.28$ & $7.85 \pm 1.21$ & 4.06 & 8.95 & $11.45 \pm 1.47$ & $18.43 \pm 7.67$ & $5.0 \pm 1.1$ & 42 \\
\hline
\end{tabular}

Table 2: Phytoplankton checklist of southwestern Caspian Sea during period of February and December 2006

\begin{tabular}{|c|c|c|c|c|}
\hline $\begin{array}{l}\text { Phytoplankton taxonomic } \\
\text { groups and species } \\
\text { Chlorophytes }\end{array}$ & February 2006 & September 2006 & October 2006 & December 2006 \\
\hline Actinastrum hantzschii Lagerheim, 1882 & - & + & - & - \\
\hline Ankistrodesmus acicularis Korshikov, 1987 & - & + & - & - \\
\hline Ankistrodesmus convolutus Corda, 1838 & - & + & - & - \\
\hline Crucigenia tetrapedia West, 1902 & - & + & - & - \\
\hline Scenedesmus acuminatus Chodat, 1902 & + & + & - & - \\
\hline Scenedesmus communis Hegewald, 1977 & - & - & - & - \\
\hline Tetraselmis Stein, 1878 & - & + & - & - \\
\hline \multicolumn{5}{|l|}{ Cyanophytes } \\
\hline Anabaenopsis cunningtonii Tylor, 1932 & - & + & - & - \\
\hline Anabeanopsis raciborskii Wolos, 1923 & - & - & + & - \\
\hline Merismopedia elegans Braun ex Kützing, 1849 & - & - & + & - \\
\hline Microsystis Kutzing, 1833 & - & - & + & - \\
\hline Oscillatoria Vaucher ex Gomont, 1893 & + & + & + & - \\
\hline Oscillatoria limosum Silva, 1996 & + & + & - & - \\
\hline Planktolyngbya limnetica Legnerova \& Cronberg, 1992 & - & + & + & - \\
\hline Spirulina laxissima West, 1907 & - & + & + & - \\
\hline \multicolumn{5}{|l|}{ Diatoms } \\
\hline Aulacoseira granulata Simonsen, 1979 & + & - & - & - \\
\hline Chaetoceros Ehrenberg, 1844 & - & + & - & + \\
\hline Chaetoceros socialis Lauder, 1864 & - & - & - & + \\
\hline Cyclotella meneghiniana Kutzing, 1844 & - & + & + & + \\
\hline Dactyliosolen fragilissimus Hasle, 1997 & - & - & - & + \\
\hline Diatoma vulgare Saint-Vincent, 1824 & - & + & - & - \\
\hline Gyrosigma attenuatum Rabenhorst, 1853 & - & + & - & + \\
\hline Melosira varians Agardh, 1827 & + & + & - & - \\
\hline Navicula Bory, 1822 & - & - & - & + \\
\hline Nitzschia Hassall, 1845 & + & - & - & - \\
\hline Nitzschia tenuirostris Manguin, 1952 & - & + & - & - \\
\hline Nitzschia acicularis Smith, 1853 & - & + & + & + \\
\hline Nitzschia lorenziana Grunow, 1880 & - & + & - & - \\
\hline Skeletonema costatum Cleve, 1878 & - & + & - & - \\
\hline Thalassionema nitzschioides Van-Heurck, 1896 & + & + & + & + \\
\hline Ulnaria ulna Jahn et al., 2001 & - & + & - & - \\
\hline \multicolumn{5}{|l|}{ Dinoflagellates } \\
\hline Gymnodinium variable Herdman, 1924 & - & + & - & - \\
\hline Peridinium latum Paulsen, 1908 & - & + & - & - \\
\hline Peridinium Ehrenberg, 1832 & - & - & + & - \\
\hline Prorocentrum cordatum Ostenfeld, 1975 & - & - & + & - \\
\hline Prorocentrum scutellum Schroder, 1990 & + & + & + & - \\
\hline Protoperidinium pallidum Balech, 1973 & + & + & + & - \\
\hline \multicolumn{5}{|l|}{ Euglenoids } \\
\hline Euglena viridis Ehrenberg, 1832 & - & + & - & - \\
\hline Trachelomonas Ehrenberg, 1833 & - & + & - & - \\
\hline
\end{tabular}

There was observed an extent variation of nutrients concentrations in 2006 (Table 1). In February, Dissolved Inorganic Nitrogen $\left(\mathrm{DIN}=2.57 \mu \mathrm{M} \cdot \mathrm{dm}^{-3}\right.$ ) was high. In December, DIN concentration dropped to value of $1.45 \mu \mathrm{M} \cdot \mathrm{dm}^{-3}$. The Dissolved Inorganic
Phosphorus (DIP) concentration ranged between 0.63 and $1.31 \mu \mathrm{M} . \mathrm{dm}^{-3}$, respectively in February and September. The average of silicate concentrations was reported $7.85 \mu \mathrm{M} \cdot \mathrm{dm}^{-3}$ in 2006 and varied from 6.50 to $9.33 \mu \mathrm{M} \cdot \mathrm{dm}^{-3}$ in October and February. 
Am. J. Applied Sci., 8 (12): 1328-1336, 2011

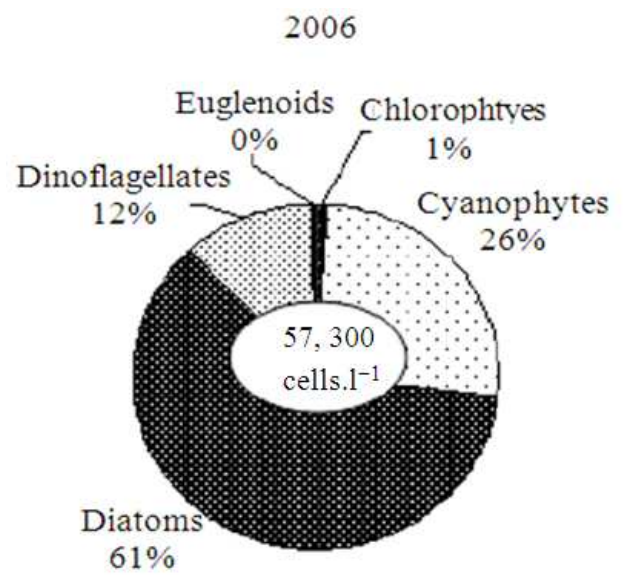

Fig. 3: Contributions of different taxonomic groups to the average total phytoplankton number at three transects and all stations in the southwestern Caspian Sea in 2006

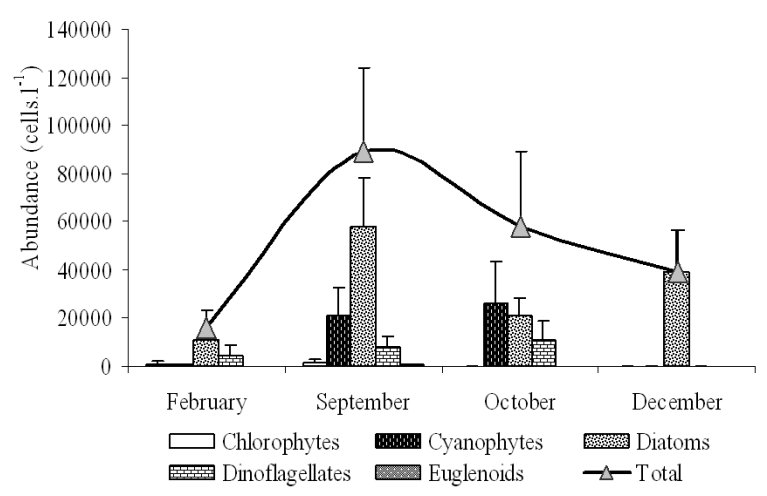

Fig. 4: Contributions of different phytoplankton groups to the total phytoplankton abundance in different months in the southwestern Caspian Sea in 2006

The Dissolved Silicate/Dissolved Inorganic Nitrogen (DSi: DIN) and the dissolved silicate/Dissolved Inorganic Phosphors (DSi: DIP) ratios were estimated 4.06, 8.95 in 2006. The Dissolved Inorganic Nitrogen (DIN) and the Dissolved Inorganic Phosphorus (DIP) concentration were significantly different during months $(\mathrm{p}<0.05)$, while the silicate concentration was not significantly different according to ANOVA findings $(\mathrm{p}>0.05)$.

Qualitative phytoplankton composition: The phytoplankton checklist, together along with annual presence (+) or absence (-) indexes and contributions of different taxonomic groups to the total phytoplankton are presented in Table 2. A total of 39 phytoplankton species were identified in 2006. Of these, $16(41.1 \%)$ were diatoms (12 genera, 16 species); 6 (15.4\%) dinoflagellates (4 genera, 6 species); 7 (17.9\%) chlorophytes (5 genera, 7 species); $8 \quad(20.5 \%)$ cyanophytes (6 genera, 8 species) and $2(5.1 \%)$ euglenoids ( 2 genera, 2 species).

Quantitative phytoplankton composition: The contributions of different phytoplankton groups to the total phytoplankton abundance during different month of 2006 are figured in Fig. 3 and 4. In this study, average number of phytoplankton were 57,300 $\pm 15,550$ cells. $1^{-1}$. Among the phytoplankton groups, diatoms formed almost half of the total abundance (61\%). Cyanophytes were the second important group contributing to total phytoplankton (26.0\%). Dinoflagellates $(12.0 \%)$, chlorophytes and euglenoids (1.0 and $0.0 \%$, respectively) were other contributors (Fig. 3).

In 2006, the diatoms Thalassionema nitzschioides Van Heurck, Cyclotella meneghiniana Kutzing (27.0, $29.0 \%$ total abundance, respectively) and the cyanophytes Oscillatoria Vaucher ex Gomont (80.2\%), were the species which have the highest abundance among phytoplankton species in the southwestern Caspian Sea. Diatoms were dominant and reaching the maximum $\left(58,133 \pm 20,235\right.$ cells. $\left.1^{-1}\right)$ during September, the total phytoplankton number changed between $89,250 \pm 35,062$ cells. $^{-1}$ and $16,200 \pm 6,664$ cells. $^{-1}$ in September and February during 2006 (Fig. 4). Statistical nonparametric test (Kruskal-wallis) showed that phytoplankton abundance were significantly different between the months in 2006 ( $\mathrm{p}<0.05$ ). Furthermore, there was a strongly positive correlation annually (significant: 0.01 level; Spearman rank correlation; 2-tailed) between phytoplankton, Dissolved Inorganic Phosphorus (DIP), water temperature during different months.

\section{DISCUSSION}

Hydrophysical characteristics: Many researchers (Dumont, 1998; Kideys and Moghim, 2003; Bagheri and Kideys, 2003; Roohi et al., 2008; Nasrollahzadeh et al., 2008a; Bagheri et al., 2010) reported that temperature variations in surface water in the southern Caspian Sea varied between $7.00^{\circ} \mathrm{C}$ (in winter) and $29.0^{\circ} \mathrm{C}$ (in summer). However, during this study, temperature variation in surface water varied between $8.83^{\circ} \mathrm{C}$ (in Febuary) and $25.74^{\circ} \mathrm{C}$ (in September) during 2006 (Table 1). The annual surface water temperature was lower than in 2006 (annual average: $18.43^{\circ} \mathrm{C}$; Table 1) as compared to 2001-2002 and 2005 
Am. J. Applied Sci., 8 (12): 1328-1336, 2011

(Nasrollahzadeh et al., 2008a; Bagheri et al., 2010; annual average: $19.83-21.14^{\circ} \mathrm{C}$ ). In this study thermocline were observed in September and October which occured in nearly $30 \mathrm{~m}$ depth and the stratification started to break up in December and February (Fig. 2). Kideys and Moghim (2003) and Zaker et al. (2007) noted, a strong thermocline located between $30 \mathrm{~m}$ and $50 \mathrm{~m}$ depths in the beginning of autumn with $15^{\circ} \mathrm{C}$ temperature, the thickness of the thermocline was located between $30 \mathrm{~m}$ and $45 \mathrm{~m}$ depths in the southern Caspian Sea, as was observed in our study, they reported the depth of the mixed layer was not the same as in the Caspian. In additions, we believed the stratification of water layers could be related to meteorological monthly fluctuations in the Caspian Sea.

In 2006, the average annual surface salinity was low (11.45 ppt; Table 1) as compared to 2001-2002 and 2005 (Nasrollahzadeh et al., 2008b; Bagheri et al., 2010; annual average: $12.54-12.20 \mathrm{ppt}$ ). The salinity varied between $9.32 \mathrm{ppt}$ and $12.25 \mathrm{ppt}$, there was a decreasing trend in the average salinity values of the surface water in February 2006 (Table 1), also salinity was increased from surface water to deep layer $(50 \mathrm{~m}$ depth; Fig. 2). These trends could be related to fresh water inputs from the Anzali wetland and the Sefidrood river in this month. According to Bagheri et al. (2010) and GWRO (2010), there was a strongly negative correlated between salinity and freshwater discharge in the southwestern Caspian Sea during 2001-2002. In additions, our findings were similar to the previous findings reported by; Dumont (1998); Kideys and Moghim (2003); Bagheri and Kideys (2003); Zaker et al. (2007); Nasrollahzadeh et al. (2008a, 2008b) in the Caspian.

In this study, average Secchi disk depth was recorded 5.0m in 2006 in the southwestern Caspian Sea (Table 1). Increase of anthropogenic inputs from Lisar and Sefidrood rivers and Anzali wetlands, has caused an accumulation of suspended inorganic and organic materials in the southwestern Caspian Sea. Nasrollahzade et al. (2008b) reported that the mean values of the Secchi depth were $6.65 \mathrm{~m}$ in 1996-97. The reduced Secchi disk depth in 2006 could be related to the increase of phytoplankton occurring during our study (57,300 cells. ${ }^{-1}$; Fig. 3) as compared to 19961997 (Nasrollahzadeh et al., 2008b; annual average: 13,000 cells..$^{-1}$ ) and the beginning of eutrophication in coastal of marine ecosystem (Yunev et al., 2005). Unfortunately, we could not talk strongly regarding this relationship, as there are no phytoplankton biomass data during 2006.
Table 3: Seasonal variations of taxonomic composition in phytoplankton and contributions of different taxonomic groups to the total phytoplankton in the southwestern Caspian Sea in 2006

\begin{tabular}{lccrr}
\hline \multicolumn{5}{c}{ Caspian Sea in 2006} \\
& 2006 & & & \\
Phytoplankton & Genus & Species & $\mathrm{f}(\%)$ & cells. $^{-1}$ \\
\hline Chlorophytes & 5 & 7 & 17.9 & 616 \\
Cyanophytes & 6 & 8 & 20.5 & 14832 \\
Diatoms & 12 & 16 & 41.1 & 34931 \\
Dinoflagellates & 4 & 6 & 15.4 & 6626 \\
Euglenoids & 2 & 2 & 5.1 & 253 \\
Total & 29 & 39 & 100.0 & 57258 \\
\hline
\end{tabular}

Annual fluctuation of phytoplankton: In our study, the number of chlorophytes and cyanophytes species (Table 3) were more than 1996-1997 (Nasrollahzadeh et al., 2008b), 11 dinoflagelltes species were present in 19961997, but we observed 6 species during 2006. Nasrollahzadeh et al. (2008b) and Bagheri et al. (2010) listed 25 and 24 species of diatoms, respectively in 19961997 and 2002, we recorded 16 in 2006, the number of euglenoids species was listed four species during 19961997, two species identified in 2006 (Table 3).

39 species of phytoplankton were identified in 2006 (Table 2 and 3), we found a decrease from 1983 (71 species: Kosarev and Yablonskaya, 1994; Dumont, 1998), 1996-1997 (50 species: Nasrollahzader et al., 2008) and 2002 (43 species: Bagheri et al., 2010) in the south of Caspian Sea. In additional, there were changes in the phytoplankton groups forming the blooms. In the 1996-1997 and 2005 study, diatoms were the dominant taxon during all seasons (59-62\%), chlorophytes and dinoflagellates made up $13-14 \%$ of the total phytoplankton abundance (Nasrollahzadeh et al., 2008b), in 2002 the dinoflagellates accounted for $56 \%$ and the cyanophytes 29\% (Bagheri et al., 2010), while in our study the diatoms accounted for $61 \%$, after diatoms; the number of cyanophytes $(26 \%)$ were prevailing phytoplankton groups in the southwestern Caspian Sea (Fig. 3).

The annual average abundance of phytoplankton reported by Kosarev and Yablonskaya (1994) 14,000 cells. $1^{-1}$; Nasrollahzadeh et al. (2008b) 13,000 cells. $1^{-1}$; Roohi et al. (2010) 39,000 cells. ${ }^{-1}$ and by us $(57,300$ cells. $1^{-1}$ ) for the period of 1962-2006 displayed increase of the phytoplankton abundance in the southern Caspian Sea. The changes of phytoplankton community in southwestern Caspian Sea in 2006 as compare with previous years, could be related to anthropogenic impact (increased water pollution) and changes in the atmospheric and hydrological regimes of the basin. Since the early 1980s, the southwestern area of the Caspian Sea has become more eutrophic (Salmanov, 1999; CEP, 2006; Stolberg et al., 2006). In addition, 
Nasrollahzadeh et al. (2008a) reported, the process of eutrophication is accompanied by a shift in the existing qualitative and quantitative relationship between the major phytoplankton groups. According to Mirzajani et al. (2010) the nutrients input via the Anzali wetland were increased in the southwestern Caspian, they documented eutrophication trend (trophic state index) varied between 42 and 46, respectively during 1995 and 2002. It seems that this trend have been continuing in 2006, the dissolved inorganic phosphors concentrations were raised from $0.37 \mu \mathrm{M} \cdot \mathrm{dm}^{-3}$ (Nasrollahzadeh et al. 2008a) to $0.96 \mu \mathrm{M} \cdot \mathrm{dm}^{-3}$ (Table 1), respectively during 1996 and 2006.

The variation of nutrient levels in the different months (Table 1) could be related to fluctuation of fresh water discharge by the rivers. Eker et al. (1999); Purcell and Decker (2005); Turkoglu (2010); Mirzajani et al. (2010) found similar occurrence in the Black Sea, Chesapeake Bay, Mediterranean Sea, and Caspian Sea. In this study, the nutrient levels fluctuations were contributed in change of phytoplankton number and composition in different months during 2006 (Table 1; Fig. 3 and 4).

Diatoms require silicate for their shells in addition to these nutrients and about $90 \%$ of the silicate input to the global marine is estimated to come from rivers (Sommer, 1994; Eker and Kideys, 2003; Humborg et al., 2004). In addition, Bagheri et al. (2010) documented, only $20.0 \%$ of the phytoplankton abundance were made up of diatoms Thalassionema nitzschioides and Cyclotella meneghiniana in the southwestern Caspian in 2001. In our study, increase diatoms T. nitzschioides and C. meneghiniana abundance $(61.0 \%)$ in 2006 could be related to increased freshwater inflow (the Sefidrood river discharge was estimated 33 and 42 million $\mathrm{m}^{3}$.year ${ }^{-1}$, respectively during 2001-2002 and 2006;

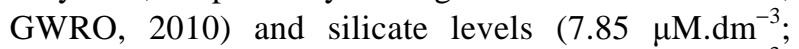
Table 1) as compare to 2001-2002 (3.70 $\mu \mathrm{m} . \mathrm{dm}^{-3}$; Bagheri et al., 2010).

Nasrollahzadeh et al. (2008b) reported with decreasing DSi:DIP ratio from 25 to 11, respectively in 1996-1997 and 2005 the abundance of cyanophytes increased from 4 to $25 \%$ in the south of Caspian Sea. In addition, Khodaparast (2006) noted in the Caspian Sea, cyanophytes bloom was observed during periods of decline in nutrients ratios. In our study, the cyanophytes number were increased in September-October (Fig. 4), It could be related to decreased of nutrients ratios in these months as compared to February and December in 2006 (Table 1). Some studies linked drastic changes in the phytoplankton community with comb jellyfish invasion in the Caspian Sea after the year 2000 (Nasrollahzadeh et al., 2008a; Ganjian et al., 2010;
Roohi et al., 2010). We could not estimate the impact of comb jellyfish on the fluctuation of phytoplankton and dominant taxa such as, diatoms and cyanophytes in 2006. According to Bagheri et al. (2010), the abundance of phytoplankton was not correlated with the number of comb jellyfish in the southwestern Caspian during 2001-2002. Accordingly, it was not possible to determine to what extent the fluctuation of the phytoplankton is due to the impact of comb jellyfish. Recent observations in other seas indicated that the changing phytoplankton community can be related to climatic variability (Polonsky et al., 2004; Bilio and Niermann, 2004). Furthermore, the fluctuations of the phytoplankton community's relationship to environmental parameters (pollutions) and nutrient upwelling were not extensively investigated up to now (Kideys et al., 2008; Bagheri et al., 2010). Since the southern Caspian Sea is influenced to a high extent by fresh water inflow with a heavy load of artificial nutrients (Dumont, 1995; Salmanov, 1999; Yunev et al., 2005; Sharifi, 2006; CEP, 2006; Stolberg et al., 2006), it is important to assess to which extent the increased eutrophication affects the phytoplankton abundance and species composition in the coasts of Caspian Sea.

\section{CONCLUSION}

Our survey documented the temporal distribution of the phytoplankton in the southwestern Caspian Sea in 2006. The study showed that diatoms such as Thalassionema nitzschioides and Cyclotella meneghiniana and cyanophyte Oscillatoria sp. numerically dominated in the southwestern Caspian Sea. We believe that hydrology variation, increased fresh water inflow via rivers, a rise in nutrient concentrations have played important roles in blooming of phytoplankton species in the Caspian Sea, which is also known from other marines. Similar studies on determination of the effects of environmental degradation on phytoplankton communiy must be taken into account in near future.

\section{ACKNOWLEGMENT}

The researchers grateful to Sam Allen for improving the English of the draft manuscript. We would like to thank the Inland Waters Aquaculture Institute (IWAI), Iranian Fisheries Research Organization (IFRO) for supporting this project. The University Sains Malaysia (USM) is also gratefully acknowledged. We greatly appreciate the assistance received from H. Babaei, E. Yosefzad, M. Saiyad 
Rahim, Y. Zahmatkesh, H. Mohsen-Pour, J. Khoushhal and M. Iran-Pour in this study.

\section{REFERENCES}

Aladin, N.V. and I. Plotnikov, 2003. The Caspian Sea. The Caspian Bulletin, pp: 1-26.

Bagheri, S. and A.E. Kideys, 2003. Distribution and abundance of Mnemiopsis leidyi in the western Iranian coasts of the Caspian Sea. Proceedings of Second International Conference on Oceanography of the eastern Mediterranean and Black Sea: Similarities and differences of two interconnected basins. Middle East Technical University, 14-18 October, TUBITAK, Ankara, Turkey, pp: 851-856.

Bagheri, S., M. Mashhor, M. Makaremi, A. Mirzajani and H. Babaei, H. Negarestan and W.O. Wan Maznah, 2010. Distribution and composition of phytoplankton in the southwestern caspian sea during 2001-2002, a comparison with previous surveys. World J. Fish and Marine Sci., 2: 416426.

Bilio, M. and U. Niermann, 2004. Is the comb jelly really to blame for it all? Mnemiopsis leidyi and the ecological concerns about the Caspian Sea. Mar. Ecol. Prog. Ser., 296: 173-183.

CEP, 2006. Strategic Action Programme (SAP) for the Caspian Sea. Caspian environment programme, Tech.Rep.

Clesceri, L.S., A.E. Greenberg and A.D. Eaton, 2005. Standard Methods for the Examination of Water and Wastewater. 21th Edn., American Public Health Association Publication, Washington, DC., pp: 1193.

Dumont, H.J., 1995. Ecocide in the Caspian Sea. Nature., 377: 673-674.

Dumont, J.H., 1998. The Caspian Lake: History, biota, structure and function. Limnol. Oceanogr., 43: 44-52.

Eker, E., L. Georgieva, L. Senichkina and A.E. Kideys, 1999. Phytoplankton distribution in the western and eastern Black Sea in spring and autumn 1995. J. Mar. Sci., 56: 15-22. DOI: 10.1006/jmsc.1999.0604

Eker, E. and A.E. Kideys, 2003. Distribution of phytoplankton in the southern Black Sea in summer 1996, spring and autumn 1998. J. Mar. Syst., 39: 203-211. DOI: 10.1016/S09247963(03)00031-9

Ganjian, A., W.O. Wan Maznah, K. Yahya, S. Najafpour and G.D. Najafpour et al., 2010. Principal componenet analysis and multivariate index for assessment of eutrophication in southern part of caspian sea. World Applied Sci. J., 9: 283-290.

GWRO, 2010. Long term rivers water inflow into the Caspian Sea, Guilan Water Resource Organization publisher, Rasht, Iran (in Persian).

Humborg, C., E. Smedberg and S. Blomqvist, 2004. Nutrient variations in boreal and subarctic Swedish rivers: Landscape control of land-sea fluxes. Limnol. Oceanogr., 49: 1871-1883.

Jamshidi, S., N.B., Abu Bakar and M. Yousefi, 2009. A study on concentrations of dissolved oxygen and chlorophyll-a in the coastal waters of babolsar. Am. J. Applied Sci., 6: 1860-1867.

Khodaparast, H., 2006. Harmful Algal Bloom in the southwestern Basin of the Caspian Sea. IFRO publisher, Tehran, Iran.

Kideys, A.E. and M. Moghim, 2003. Distribution of the alien ctenophores Mnemiopsis leidyi in the Caspian Sea in August 2001. Mar. Biol., 142:163-171. DOI 10.1007/s00227-002-0932-4

Kideys, A.E., N. Soydemir, E. Eker, V. Vladymyrov and D. Solovievn and F. Melin, 2005. Phytoplankton distribution in the caspian sea during march 2001. Hydrobiology, 543: 159-168. DOI: 10.1007/s10750-004-6953-X

Kideys, A.E., A. Roohi, E. Eker, F. Melin and D. Beare, 2008. Increased chlorophyll $a$ levels in the southern caspian sea, following an invasion of jellyfish. Res. Lett. Ecology, Hindawi Publishing Corporation, Egypt, pp: 1-4. DOI: $10.1155 / 2008 / 185642$

Kosarev, A.N. and E.A. Yablonskaya, 1994. The Caspian Sea, SPB Academic Publication, Russia.

Lahijani, H.A., V. Tavakoli and A.H. Amini, 2008. South caspian river mouth configuration under human impact and sea level fluctuations. Environment Sci., 5: 65-86.

Mirzajani, A.R., S.H. Khodaparast, H. Babaei, A. Abedini and A.D. Ghandi, 2010. Eutrophication trend of Anzali wetland based on 1992-2002 data. J. Environ. Stud., 35: 19-21.

Makaremi, M., J. Sabkara and A. Mirzajani, 2007. Investigation on nodularia anomalous algal blooming in the southwestern caspian sea. Proceedings seventh conference on Marine Sciences and Technology. Emam Khomeini University, 26-27 November, ISMSI, Nowshahr, Iran, pp: 2-6. 
Nasrollahzadeh, H.S., Z.B. Din, S.Y. Foonga and A. Makhlough, 2008a. Spatial and temporal distribution of macronutrients and phytoplankton before and after the invasion of the ctenophore, Mnemiopsis leidyi, in the Southern Caspian Sea. J. Chem. Ecol. 24: 233-246. DOI: 10.1080/02757540802310967

Nasrollahzadeh, H.S., Z.B. Din and A. Makhlough, 2008b. Variations in nutrient concentration and phytoplankton composition at the euphotic and aphotic layers in the Iranian coastal waters of the southern Caspian Sea. Pak. J. Biol. Sci., 11: 1179-1193.

Nasrollahzadeh, H.S., Din, Z.B. and A. Makhlough, 2008c. Trophic status of the Iranian Caspian Sea based on water quality parameters and phytoplankton diversity. Cont. Shelf Res., 28: 1153-1165. DOI: 10.1016/j.csr.2008.02.015

Newell, G.E. and R.C. Newell, 1977. Marine Plankton: A Pratical Guide. 5th Edn., Hutchinson, London, ISBN: 0091318718, pp: 244.

Polonsky, A.B., D.V. Basharin, E.N. Voskresenskaya and S. Worley, 2004. North Atlantic Oscillation: description, mechanisms and influence on the Eurasian climate. Phys. Oceanogr., 15: 96-113.

Prescott, G.W., 1962. Algae of the Western Great Lakes Area. Wm. C. Brown Company Publishers. Dubuque, Iowa. pp: 977. ISBN: 978-0-12-219135-0

Purcell, J.E. and M.B. Decker, 2005. Effects of climate on relative predation by scyphomedusae on copepods in Chesapeake Bay during 1987-2000. Limnol. Oceanogr., 50: 376-387.

Roohi, A., A.E. Kideys, A. Sajjadi, A. Hashemian and R. Pourgholam, H. Fazli, A.G. Khanari, and E. Eker, 2010. Changes in biodiversity of phytoplankton, zooplankton, fishes and macrobenthos in the Southern Caspian Sea after the invasion of the ctenophore Mnemiopsis Leidyi. Biol. Invasions., 12: 2343-2361. DOI 10.1007/s10530-009-9648-4
Roohi, A., Z. Yasin, A.E. Kideys, A.T. Hwai, A.G. Khanari and E. Eker, 2008. Impact of a new invasive ctenophore (Mnemiopsis leidyi) on the zooplankton community of the Southern Caspian Sea. Marine. Ecol., 29: 421-434. DOI: 10.1111/j.1439-0485.2008.00254.x

Salmanov, M.A., 1999. Ecology and Biological Productivity of the Caspian Sea. Institute of Zoology, Baku, Azerbaijan.

Sharifi, M., 2006. The pattern of caspian sea water penetration into anzali wetland: Introduction of a salt wedge. Caspian J. Environ. Sci., 4: 77-81.

Sommer, U., 1994. Are marine diatoms favoured by high Si/N ratios? Mar. Ecol. Prog. Ser., 115: 309-315.

Sournia, A., 1978. Phytoplankton Manual. UNESCO, Paris. ISBN: 92-3-101572-9

Stolberg, F., O. Borysova, I. Mitrofanov, V. Barannik and P. Eghtesadi, 2006. Global international waters assessment Caspian Sea, Regional Assessment Report, University of Kalmar, Sweden.

Stone, R., 2002. The Caspian ecology teeters on the brink, Science., 295: 430-433.

Tiffany, L.H. and M.E. Britton, 1971. The Algae of Illinois.1st Edn., Hansfer Publishing Company, New York, USA., ISBN: 0028535308, pp: 407.

Turkoglu, M., 2010. Temporal variations of surface phytoplankton, nutrients and chlorophyll a in the Dardanelles (Turkish Straits System): a coastal station sample in weekly time intervals. Turk. J. Biol., 34: 319-333. DOI: 10.3906/biy-0810-17

Yunev, O.A., S. Moncheva and J. Carstensen, 2005. Long-term variability of vertical chlorophyll $a$ and nitrate profiles in the open Black Sea: eutrophication and climate change, Mar Ecol Prog Ser., 294: 95-107.

Zaker, N.H., P. Ghaffari and S. Jamshidi, 2007. Physical study of the southern coastal waters of the caspian sea, off babolsar, mazandaran in iran. J. Coast Res., 50: 564-569. 